\title{
MUHAJIRIN AMSAR CONTRIBUTION ON LEGAL HADÎTS INTERPRETATION
}

\author{
Masykur Hakim \\ Universitas Islam Negeri (UIN) Syarif Hidayatullah Jakarta \\ Jl. Ir. H. Juanda No.95, Ciputat, Jakarta Selatan \\ E-mail: masykur.hakim@uinjkt.ac.id
}

\begin{abstract}
Muhajirin Amsar Contribution on Legal Hadits Interpretation. Muhajirin Amsar is a native Betawi scholars. Muhajirin Amsar explained haditts by ignoring other scholars opinion in terms of grammar, so that the reader can immediately understand the content of the hadits. He also did not provide his own opinion after the scholars opinion, it seems he more likely put the reader to choose freely due to the problem as the issue of khilâfiyyah.
\end{abstract}

Keywords: hadîts, matan, syar $\underline{h}$, khilâfiyyah

\begin{abstract}
Abstrak. Kontribusi Muhajirin Amsar dalam Penafsiran Hadits Hukum. Muhajirin Amsar adalah ulama Betawi asli. Muhajirin Amsar menjelaskan Hadis dengan mengabaikan pendapat ulama lain dalam hal tata bahasa sehingga pembaca dapat langsung memahami isi Hadis. Dia juga tidak memberikan pendapatnya sendiri setelah pendapat ulama. Hal ini tampaknya ia lebih cenderung menempatkan pembaca untuk memilih secara bebas masalah-masalah yang masuk ranah khilâfiyyah.
\end{abstract}

Kata kunci: hadis, matan, syarh, khilâfyyah

\section{Introduction}

The word 'contribution' is originally derived from English word which means to help or donations, for example "his contribution to art literature was very great, which meansa very large contribution to the literature or a meaningful contribution to charity which equal understanding to donations to charity. ${ }^{1}$

Furthermore, etymologically speaking the word 'syarh' (interpretation) is derived from the Arabic syara $\underline{a} a$ which means'to explain', 'to open', 'to pave'. ${ }^{2}$ And too, the word 'syarb' is usually used to describe the meaning of the hadits, while the word 'tafsîr' is usually used to explain the meaning of the Quran. For the impelementation, the word tafsir-is exclusively concerning with the interpretation of the Quran meaning. While syar $\underline{h}$, relies on $\underline{h}$ aditts interpretation, its content, conclusion (istinbâth) for both legal or moral of the Prophet's words or explaining other disciplines. ${ }^{3}$

Recived: 13th March 2014, revised: 28th August 2014, accepted: 3th December 2014.

${ }^{1}$ Peter Salim, The Contemporary English-Indonesian Dioctionary, (Modern English Press, Jakarta), p.403.

2 Muhammad ibn Mukarram ibn al-Manzhûr, Lisân al-Arab, (Beirut: Dar Shadr, 1990), Vol. 2, p.497-498.

${ }^{3}$ Nizar Ali, (Ringkasan Disertasi), Kontribusi Imam Nawawi dalam Penulisan Syarh Hadits, (Yogyakarta: 2007), p.4.
Meanwhile, according to the definition the word syar $\underline{h}$ hadits is to explain and to interpret the meaning of all its contents of hadits both legal and wisdom ${ }^{4}$. The definition very much relies on the matan of haditts where as syar $\underline{h}$ includes all components of $\underline{h} a d \hat{t} t$, both sanad and matan is to explain the validity and disability the sanad (chain of hadits narrators) and matan hadits as well as its meaning, and conclusion toboth legal and wisdom. ${ }^{5}$

With the above definition, the haditts interpretation (syarb) broadly covers the following three important points: (1) Describing the both quantity and quality of hadits, in terms of the sanad or the matan, both in general and detail. This includes the explanation of its pathways, origin, identity and characteristics of the narrators, as well as analysis of the matan in the view language rules. (2) Elaborating the meaning and intention of hadits, which include the explanation how to read the specific pronunciation, grammatical, lexical and each intended meaning. (3) Discovering the law and wisdom contained therein which includes istinbatth toward the law and the

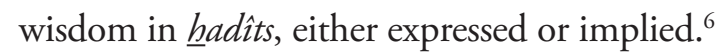

\footnotetext{
${ }^{4}$ Mujiono Nurcholish, Metodologi Syarh Hadits, (Bandung: Fasygil Group, 2003), p.3.

${ }^{5}$ Mujiono Nurcholish, Metodologi Syarh Hadits, p.3.

${ }^{6}$ Mujiono Nurcholish, Metodologi Syarh Hadits, p.4.
} 
The interpretation (syar $\underline{b}$ ) of hadits also means researching, then explaining each component contained in haditts. In general, the hadîts scholars describe two components namely the sanad and the matan. The sanad is a series of narrators who transmit the matan from primary sources. While the matan is haditts narration as the supporting elements of its meaning.?

\section{History and Development of Syarh $\underline{\text { Haditts }}$}

Historical development of syar $\underline{h} \underline{h}$ adîts experiencing a long story and dynamic. Hasbi al-Shiddiqy ${ }^{8}$ found syar $\underline{h}$ hadits developments occurred in the seventh period or the last period of the development of the haditts and its sciences. The Seven periods made by Hasbi AlShiddiqy are as follows: (1) The birth of the hadîts up to the Prophet passed away; (2) The restriction of haditts narration; (3) The development and the journey of compiling hadîts narration, since the late $41 \mathrm{AH}$ up to 1 $\mathrm{AH}$; (4) The codification of haditts in the second Centuy AH.; (5) The screening and selection of haditts in the $3^{\text {rd }}$ century of Hijriah; (6) The codification of the forgotten hadits since the beginning of the fourth century up to $646 \mathrm{AH} ;(7)$ The Writing books of syarh, takhrîj and so it began in the middle of seventh century AH.?

As for Muhammad 'Abd al-'Zîz al-Khûlî divides syarh hadits development phase into five periods, and the last period is systematization, compilation and writing the the book syar $\underline{h}$ since the fourth century AH. ${ }^{10}$ While Other haditts figure, Nuruddin 'It divides the history of the science of haditts into seven phases: (1) The birth of the haditts sciences since the companions period up to the hundredth century AH; (2) The completion, since the beginning of the second century to the beginning of the third century AH; (3) The compilation haditts sciences books separately, since the third century until the middle of the fourth century AH; (4) The compilation of main books of haditts sciences since the middle of the fourth until the seventh century AH; (5) The maturation and refinement of of hadits sciences since the end of the seventh century until the tenth century AH; (6) The stagnation, since the tenth century to the fourteenth century $\mathrm{AH}$; (7) The second resurrection since the fourteenth century AH and so on. ${ }^{11}$

Pragmatically speaking, the syar $\underline{h} \underline{h}$ adîts has actually

\footnotetext{
${ }^{7}$ Ajaj al-Khâtib, Ushûl al-Hadîts, (Jakarta: GMP, 2007), p.12.

${ }^{8}$ Hasbi al-Shiddiqy, Sejarah Pengantar Ilmu Hadits, (Jakarta: Bulan Bintang, 1980), p.46-47.

${ }^{9}$ Hasbi al-Shiddiqy, Sejarah Pengantar Ilmu Hadits, p.47.

${ }^{10}$ Muhammad 'Abd al-'Azîz al-Khûlî, Târîkh Funûn al- $\underline{\text { Hadîts, }}$ (Jakarta, Dinamika Berkah Utama, t.t), p.12.

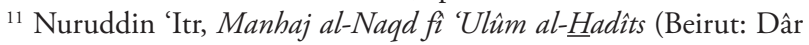
al-Fikr, 1979), p.72.
}

occurred at the birth of the haditts itself, namely by the Prophet verbally and continued during the period of companions by the scholars, so the periodization of the history of syar $\underline{h}$ haditts seems necessary to be distinguished to the historical periodization of the development of the

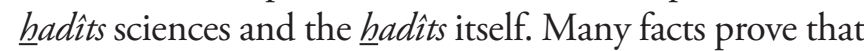
syar $\underline{h}$ hadits verbally is often done by the Prophet and the companions. Therefore, the period of the historical development of syar $\underline{h} \underline{\text { hadits }}$ mainly divided into three periods; are at the time of syar $\underline{b} \underline{\text { hadits }}$ at the time of the early period of haditts (fí 'ashr al-risâlah), syar $\underline{h}$ hadits at the time of hadîts narration and compilation ( $f \hat{i}$ ashr alriwâyah wa al-tadwîn), and syarh $\underline{h}$ adîts after the period of the compilation (ba'da al-tadwin). ${ }^{12}$ The latter of those periods is the time when the emergence of several books

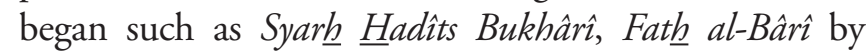
Ibn Hajar al-'Asqalânî, Umdat al-Qârî by Badr al-Dîn al-'Aynî, Irsyâd al-Sârî by Al-Qathalânî, Fâid al-Bârî by Nur Shah Anwar al-Kasymiriy, and so on for syarh $\underline{h}$ haditts books.

As it is known that Bulîgh al-Marâm by Ibn $\underline{\text { Hajar }}$ al-Asqalân $\hat{i}^{13}$ concerning with the legal aspects of haditts

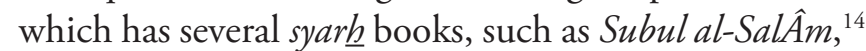
the work of al-Shan'ânî and Mishbâh al-Dhalâm by Muhajirin Amsar. The discussion is focused on Mishbâh $\underline{\underline{h}}$ al-Dhalam, ${ }^{15}$ Muhajirin Amsar's work and his methods in explaining the legal aspects of haditts, Although it is possible to discuss other methods other than the

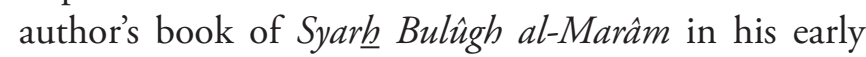
time such as al-Shan'ânî.

\section{The Compiler of Bulûgh al-Marâm}

The compiler of Bulîgh al-Marâm is Ahmad ibn 'Alî ibn Muhammad Abû al-Fadh al-Kannânî al-Syâfi'î known as Ibn Hajar al-'Asqalânî, a gonfalonier for sunnah, justices, hâfizh and hadìts narrator. He was born in Egypt in Sya'bân773 AH. In the country where he grew up, he memorized the Quran, al-Hawî, and a summary of $I b n$ al- $\underline{H} \hat{a j i} i b$. He sailed to accompany one of his closest colleague to Mecca, hardly learned hadits and love the subject. He earnestly studied and obtained from the experts in a number of countries such as Hejaz, Sham and Egypt, especially he learned to al-Bulqaynî and Ibn al-Mulaqqan in Iraq and finally they gave him authorization to teach and give fatwa. $\mathrm{He}$

\footnotetext{
${ }^{12}$ Mujiono Nurcholish, Metodologi Syarh Hadits, h.35.

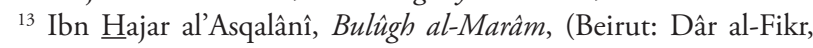
1980).

${ }^{14}$ Muhammad ibn Ismầîl al-Amîr al-Yamanî al-Shan'ânî, Subul alSalâm, (Delhi,India: Maktabah Isyầât, 1987), 3.

${ }^{15}$ Muhammad Muhajirin Amsar, Mishbâh al al-Dhalâm, (Jakarta: Manhal al-Nasyi'in Press, 1995), p.73.
} 
also learned Islamic legal theory to al-'Izz ibn Jamâah, the language to al-Majd Fairuzabadî, Arabic to al-Imarî, literature and arûdh to al-Badr al-Busytakî. Then he tried to spread the haditts and consistently engaged in it to several places, either through teaching or compilation of books for more than 21 years. ${ }^{16}$

As for his writing not less than 150 titles, and some of which are related to the disciplines of haditts such as Al-Ishâbah fî Asmâ al-Shahâabah, Tahdzîb al-Tahdzîb, AlTaqrîb, Tajîl al-Manfa'ah bi Rijâl al-Arba'ah, Musytabih al-Nisbah, Talkhîsh al-Kabîr fî̀ Takhrîj A Ahâdîts al-Rafî̀ al-Kabîr, Takbrîj al-Mashâbih and Ibn Hîajib, Takhrîj al-Kasysyâf, Ittihihâf al-Mahârah, Al-Muqaddimah, Badl al-Mâunn, Nukhbah al-Fikr and its interpretation and the most monumental in this field is Fath al-Bârî $f_{\hat{\imath}}$ Syarh Shahîh al-Bukhariy. After compiling this sunnah encyclopedia, he passed away after isyâ 'time on Saturday evening of 18th of Dzû al-Hijjah in 852 AH. ${ }^{17}$

\section{Biography of Muhajirin Amsar}

Mishbâh al-Zhalâm compiler is Muhajirin Amsar al-Dârî, Betawi scholar and religious expert (ulama), born in Kampung Baru Cakung Barat, Cakung, East Jakarta on November 10, 1921. The name al-Dâriyis originally taken from Ma'had Dâr al-Ulùm, where he studied at Mecca. The most of its alumni made the use of the name al-Dârî behind each name.

Muhajirin Amsar learned to several scholars as can be noted to Guru Asmat in his homeland, Kampung Baru Cakung Barat, H.Mukhayar, H.Ahmad, KH Hasbiallah Klender, H.Anwar, H.Hasan Murtaha, Sheikh Muhammad Tahir Ahmad ibn Muhammad, the disciple of Syaykh Mansur KH Salih Ma’mun Banten, KH Abdul Majid and Habib Ali Kwitang. Then he continued his formal education at Dâr al-Ulûm al-Diniyyah, Mecca Saudi Arabia from 1947 up to 1955. While in Mecca he also enrolled in the foyer of Masjid al-Haram and every summer he learned in Masjid Nabawi in Medina. ${ }^{18}$

In addition to his teaching at his religious school (Pesantren) Al-Nida Al-Islamiy Bekasi and some places outside the Pesantren, Muhajirin Amsar diligently wrote the book in a variety of themes, ranging from hadits sciences, Islamic jurisprudence, logic, theology, and so forth, which were written in Arabic. Among the works he wrote as the following: (1) Mishbâh al-Zhalâm Syar $\underline{h}$

\footnotetext{
${ }^{16}$ Muhammad ibn Ismầîl al-Amîr al-Yamanî al-Shan'ânî, Subul alSalâm, p. 3 .

${ }^{17}$ Muhammad ibn Ismầîl al-Amîr al-Yamanî al-Shan'ânî, Subul alSalàm, p. 4.

${ }^{18}$ Ahmad Fadli HS, Ulama Betawi, (Jakarta: Manhal al-Nasyi' in Press, 2011), p.186.
}

Bulîgh al-Marâm, 8 volumes, on syara $\underline{h}$ hadîts relarted with legal interpretation. (2) Îdhâh al-Mawrid, 2 volumes on Islamic legal theory. (3) Fann al-Mathla'ah, 3 volumes, on Arabic grammatical. (4) Qawẩid alNahwiyyah, 2 volumes, on Arabic grammatical. (5) Mahfüzhât on Arabic. (6) Al-Bayân on Arabic. (7) Mukhtârât al-Balâghah on Arabic. (8) Mulakhkhash alTa'lìqât 'alâ Matn al-Jawhariyyah, on Islamic theology. (8) Syarb Tàlîqât 'alâ Matn al-Jawhariyyah on Islamic theology. (9) Taysîr al-Wushûl fî 'Ilm al-Ushûl, on Islamic legal theory. (10) Istikhrâj al-Furû' 'alâ al-Ushôl,, on Islamic legal theory. (11) Khilafiyyah on Islamic legal theory. (12) Filsafah al-Tasyrî̀ on Islamic legal theory. (13) Márif Thuruq al-Ijtihâd on Islamic legal theory. (14) Takbrîj al-Furû̀ alâ al-Ushîl on Islamic legal theory. (15) Al-Qawl al-Hasîs fì Mushthalâh alHadîts on hadîts sciences. (16) Tàlîqât Alầ Matn AlBayqûnî on hadîts sciences. (17) Al-Istidzkâr fî Taqyîd Mlâ Budda Min Thsalât al-Anwâr on hadîts sciences. (18) Al-Madârik fì Al-Mantiq on logic. (19) Al-Nahj al-Mathlûb fî Al-Manthiq al-Marghûb on logic. (20) AlQawl al-Fẩid fì Ilm Al-Farẩid on inheritance sciences. (21) Mar'at Al-Muslimin on history. (22) Al-Muntakhab min Târîkh Dawlah Bani Umayyah on history. (23) Târîkh Al-Adab Al-Arabî on history of Arabic literature. (24) Târîkh Muhammad Rasulillah Saw wa Khulafâ alRâsyidîn on history. (25) Al-Tanwîr fî-Ushîl Al-Tafsîr on tafsir al-Quran sciences. (26) Tathbîq Al-Âyat bi al- $\underline{\text { Hadîts }}$ on tafsir al-Quran sciences. (27) Qawẩid al-Khams al-Bahiyyah on Islamic legal theory. (28) AlSaqâyah al-Mariyyah fî̀ al-Babts wa al-Munâzharah on the methods of debate. (29) Al-Qur'u Al-Sam'ufi

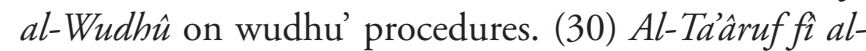
Tashawwwuf on Sufism. ${ }^{19}$

\section{Muhajirin Amsar and The Chain of Narrators (sanad) of Hadîts Bulûgh al-Marâm}

Ibn Al-Mubârak stated that isnâd or sanad is an important part of Islam, even if the absence of the sanad surely everyone can conveys freely. ${ }^{20}$ Here is the sanad of Muhajirin Amsar in learning the haditts that he

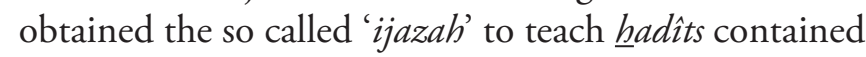
in the book of Bulügh al-Marâm to others.

He learned hadîts Bulîgh al-Marâm to Syaykh Muhammad Yâsîn al-Fadanî al-Makkî, Syaykh Muhammad Yâsîn 'Alî ibn Husin al-Mâlikî, Al-Sayyid Abî Mâlikî Syathâ Bakr Al-Makkî, Al-Makkî of Sayyid Aḥmad ibn Zaynî Dahlân Al-Makkî, Zaynî Dahlan of

\footnotetext{
${ }^{19}$ Ahmad Fadli HS, Ulama Betawi, p.186.

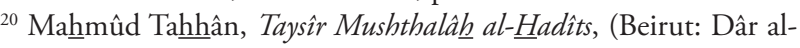
Fikr, 1991), p.15.
} 
Utsmân ibn Hasan al-Dimyâthî, Al-Dimyâthî of 'Abd Allâh ibn al-Syarqowî Hejaziy, Al- Syarqowî of AlSyams Muhammad ibn Sâlim Al-Ziyâdî, Al-Ziyâdî of Al-Syams Muhammad ibn al-'Ala al-Babilî, Al-Babilî of Sâlim ibn Muhammad Al-Nahurî, Al-Nahurî of AlNajm Muhammad Ahmad al-Ghaythî, Al-Ghaythî of al-Qâdhî Zakariyâ ibn Muhammad al-Ansharâ, Zakariâ al-Ansharî of Aḥmad al-Hâfizh ibn 'Alî ibn Hajar al'Asqalânî, the compiler of Bulùgh al-Marâm. ${ }^{21}$

\section{Muhajirin Amsar Method in His Book, Misbâh al- Dhalâm}

The word method is derived from English, method which means a planned and orderly way to do something, such as His method of teaching is very up to date which meant his teachingmethodis very modern way. ${ }^{22}$ Here is the method used by Muhajirin Amsar in explaining the meaning of the haditts concerning with sleep which could abrogate the matter of wudlü.

The hadîts text concerning with sleep which could abrogate wudhu':23

$$
\begin{aligned}
& \text { عن أنس بن مالك رض الله تعالى عنه قال كان أصحاب }
\end{aligned}
$$

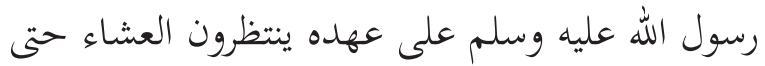

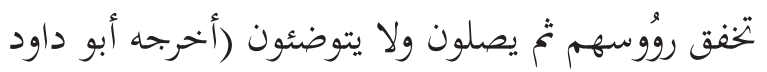

$$
\begin{aligned}
& \text { وصححه الدارقطنى وأصله فن مسلم) }
\end{aligned}
$$

It is clear that the person who sleeps in his sitting does not abrogate his $w u d h \hat{u}$, both long and short sleep, as long as he does not make any moves from his seat. This relies on Syafi'i school of thought, Malik, Ahmad. Ash $\underline{h} \hat{a} b$ al-Ráy argued briefly when the person sleeps longer, it will definitely abrogate his wudh $\hat{u}$.

On the matter of sleep which related to someone's $w u d h \hat{u}$, there are vary in idea which rely on eight schools of thought: (1) Sleeping is not abrogating wudh $\hat{u}$ ' what ever the circumstances, as it is narrated from Abû Mûsâ al-'Asy'arî, Sa'îd ibn Musayyab, Abû Majlaj and others. (2) Sleeping can abrogate the wudhû'regardless the sleep is much or little. Nawâwî

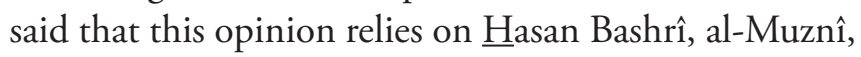
and Abû 'Ubayd al-Qâsim. (3) Sleeping which takes much in time can abrogate the wudh $\hat{u}$ ' what ever the circumstances. Nawâwî said that this opinion relies on Malik, Ahmad in one of his narration. Rabi'a, Zuhri and Awzầî tend to this school of thought. (4) If the

${ }^{21}$ Muhammad Muhajirin Amsar, Misbah al-Dhalam, p.6

${ }^{22}$ Peter Salim, The Contemporary English-Indonesian Dioctionary, p. 167 .

${ }^{23}$ Muhammad Muhajirin Amsar, Mishbâh al-Dhalâm, Vol.1, p.73. sleeping in one pattern of those who pray like people are bowing, prostration and standing is not abrogating it, either in or outside the prayer (shalât). If the sleep lies or supine can also abrogate it. Nawâwî said that this stand point very much relies on Abû Hanîfah, Dâwud schools of thought and the statement of Syafi'i. (5) The matter does not abrogate it except it occurred in bowing and prostration. The idea relies on Ahmad narration. (6) The matter is not abrogate it in all circumstances and abrogate it outside the prayer (shalât). This opinion is attached to Zayd ibn 'Alî and Abû Hanîfah. (7) If the matter occurred firmly on the seat does not abrogate it, either sleep takes much in time or little and in or outside the prayer. This idea relies on Syafi' ${ }^{2}{ }^{24}$

$$
\text { وفى الحديث العينان وكاء السه فمن نام فليتوضاء.25 }
$$

The above hadits shows that both eyes are bound to the rectum. If the person slept it would tie it apart and he did not know what matches out of the rectum. If the mentioned hadits general in meaning then it devoted to the hadits which relies on the bowed head. Therefore, the hadits compatibility with the translation of the

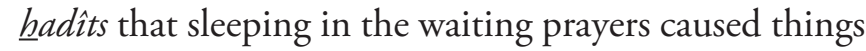
were not moving in. So that the seat does not abrogate it. The $\underline{\text { hadits }}$ in the context of waiting for prayer time at the night of Ramadhan. ${ }^{26}$

Another example is the hadits related to the qunût in shubuh prayer time which reads:

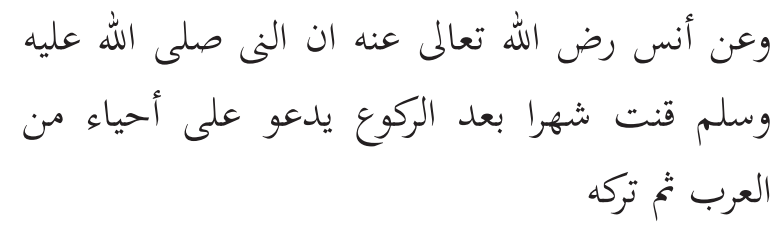

For Ahmad and al-Dâruquthnî from other narration added as for the shubuh prayer of the Prophet always do the qunut up to his passed away. Muhajirin explained the matter as follows: Muslims agreed to the haditts related to the matter of the qunut then agreed that Zhuhur, Ashar, Maghrib and Isyâ, the Prophet did not do the qunît unless there is a disaster (nâzilab) and a dispute occured at shubuh for the prayer time.

With this $\underline{h}$ adîts al-Syâfî̀ argued that the matter of the qunût is recommended caused the Prophet did it up to his passing away and it was part of the sunnah ab'adh that if the matter is forgotten need to be equipped by performing the so called the sujûd sahwi.

Muhajirin said that he received a sequential manner

\footnotetext{
${ }^{24}$ Muhammad Muhajirin Amsar, Mishbâh al-Dhalâm, Vol. 1, p.74

${ }^{25}$ Muhammad Muhajirin Amsar, Mishbâh al-Dhalâm, Vol.1, p.74.

${ }^{26}$ Muhammad Muhajirin Amsar, Mishbâh al-Dhalâm, Vol.1, p.75.
} 
(musalsal) of the hadits related to the matter of the qunût dawn of his lecturer, Muhammad Yâsîn. He said that in concatenated he received Syâfi'iyyah and not from other scholars. Mâlik said, the Prophet do perform the qunût before bowing. The differences of opinion occurred between Syâfi'iyyah and Mâlikiyyah that the performance of the qunut after bowing or before it. However, they agreed upon the matter of

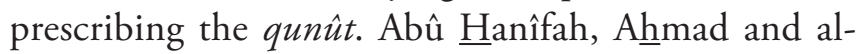
Tsawrî said that the matter was not recommended, mainly in shububband other times except the prayer of witir. As the matter of the qunût nâzilah they agreed to its existence caused the Prophet did it for about a month then left it. ${ }^{27}$

The qunut means prayer while standing in the prayer for a specific place. Syâfi'iyyah said that the qunut moment is after bowing at the last cycles (raka'at). The qunut is indeed recommended loudly at the jahr prayer and silent while at the sirr. ${ }^{28}$

Providing the interpretation for the same haditts, alShan'ânî said that Anas ibn Mâlik was asked whether the Prophet did the qunut before or after bowing. He said that the Prophet did it after bowing for a month, after he saw that 70 people whom he sent to the polytheists were killed and the Prophet prayed for the syuhadâ (martyrs). Several hadîts that narrated by Anas related to the matter seem contradict each other, then al-Shan'ânî collected all of hadîts and found all are authentic hadîts. ${ }^{29}$ The qunît was done before bowing or later, he said that the qunût which done before bowing caused of the performance of a longstanding for reciting the surrah of the Quran. He said that the best of which is the establishment of long prayers. The qunut which performed by the Prophet after bowing in prayer had been done for a month. Then continued this practice until he passed away. If the the long standing in his prayer, indeed caused of reciting the Quran and praying at the same time, said al-Shan'ânî that Anas seems disagreed upon the matter of the Prophet who habitually do the qunut in shubuh prayer time in his life, up to his passed away. The long standing in prayer is generally applicable to all the five times prayers a day. ${ }^{30}$

As for the hadits of Abû Hurayrah R.a. which is selected and edited by al-Hâkim that the Prophet when lifting his head from bowing in the second raka'ah at

\footnotetext{
${ }^{27}$ Muhammad Muhajirin Amsar, Mishbâh al-Dhalâm, Vol.2, p.51.

${ }^{28}$ Muhammad Muhajirin Amsar, Mishbâh al-Dhalàm, Vol.2, p. 52.

${ }^{29}$ Muhammad ibn Ismầîl al-Amîr al-Yamanî al-Shan'ânî, Subul alSalâm, Vol.1,p.317.

${ }^{30}$ Muhammad ibn Ismầîl al-Amîr al-Yamanî al-Shan'ânî, Subul alSalâm, Vol.1, p.317.
}

shubuh prayer time, he raised his hands and prayed Allahumma Ihdinî fì man Hadayt until the end. 'Abd Allâh ibn Sa'îd al-Maqbarî found that praying in the second raka'ah at shubuh prayer time is habits for the Salaf and Khalaf, al-Hâdî, al-Qâsim, Abû Zayd 'Alî and al-Syâfi'î although differed in narrating the pronunciation. Al-Hâdî with praying that adopted from the Quranic verses by reciting and al-Syâfîi read Allabumma Ihdinî fì man Hadayt until the end. ${ }^{31}$

\section{Closing Remarks}

Referring to the above methods used in the two

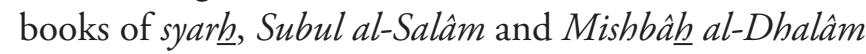
show that both lecturers have similarities and differences in explanation. The similarities of the both scholars devide into eight points of opinion concerning with the hadits related to the matter of sleep and wudh $\hat{u}$. The difference is that al-Shanânî explained the hadîts in terms of grammar before explaining its contain, then he provides his own opinion after the other earlier scholars opinion. While KH Muhajirin Amsar explained hadîts by ignoring other scholars opinion in terms of grammar, so that the reader can immediately understand the content of the haditts. He also did not provide his own opinion after the scholars opinion, it seems he more likely put the reader to choose freely due to the problem as the issue of khilaffyyah. Each has its own added value and has made a significant contribution in the context of hadits legal description that contained in the book of Bulügh al-Marâm including Muhajirin Amsar, The native Betawi scholars. []

\section{Biblioghrapy}

Salim, Peter, The Contemporary English-Indonesian Dioctionary, Modern English Press, Jakarta.

Ibn al-Manzhûr, Muhammad ibn Mukarram, Lisân alArab, Beirut: Dar Shadr, 1990.

Ali, Nizar, (Ringkasan Disertasi), Kontribusi Imam Nawawi dalam Penulisan Syarh Hadits, Yogyakarta: 2007.

Nurcholish, Mujiono, Metodologi Syarh Hadits, Bandung: Fasygil Group, 2003.

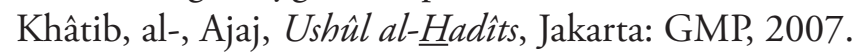
Ass-Shiddiqy, Hasbi, Sejarah Pengantar Ilmu Hadits, Jakarta: Bulan Bintang, 1980.

Khûlî, al-, Muhammad 'Abd al-'Azîz, Târîkh Funûn alHadîts, Jakarta, Dinamika Berkah Utama, t.t.

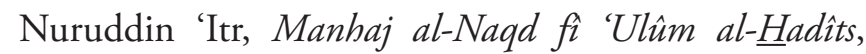
Beirut: Dâr al-Fikr, 1979.

\footnotetext{
${ }^{31}$ Muhammad ibn Ismầil al-Amîr al-Yamanî al-Shan'ânî, Subul alSalàm, Vol.1,p.317.
} 
Ibn Hajar al'Asqalânî, Bulügh al-Marâm, Beirut: Dâr al-Fikr, 1980

Shan'ânî, al-, Muhammad ibn Ismầîl al-Amîr alYamanî, Subul al-Salâm, Delhi,India: Maktabah Isyầât, 1987.
Fadli HS, Ahmad, Ulama Betawi, Jakarta: Manhal alNasyi' in Press, 2011.

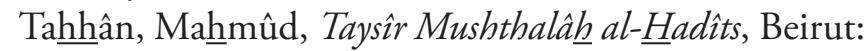
Dâr al-Fikr, 1991.

Amsar, Muhammad Muhajirin, Mishbâh al-Dhalâm, Jakarta: Manhal al-Nasyi’in Press, 1995. 